A N N A L E S

UNIVERSITATIS M A R A E C URIE-SKŁODOW S A

LUBLIN - POLONIA

VOL. LXXII

SECTIO F

2017

The Tadeusz Manteuffel Institute of History Polish Academy of Sciences

\title{
PIOTR OKNIŃSKI
}

p.okninski89@gmail.com

\section{Forming the Spatial and Institutional Framework of a Communal Town in Medieval Lublin (13 th and $14^{\text {th }}$ centuries)}

Formowanie się ram przestrzennych i instytucjonalnych gminy miejskiej

w średniowiecznym Lublinie (XIII i XIV w.)

\section{SUMMARY}

This article deals with the formation of institutional structures and spatial frames of the late medieval urban settlement, which developed throughout the $13^{\text {th }}$ and $14^{\text {th }}$ centuries on the Old Town-Hill in Lublin. Author reinterprets the findings of previous studies on Lublin's history in the light of Max Weber's concept of Western-European model of the urban community. Town of this type is characterized as an autonomous administrative unit, having its own communal government and jurisdiction system, as well as a territorial entity of defined boundaries. Author distinguishes three steps of the urban development in Lublin: 1) establishment of an early urban settlement along today's Grodzka Street, in the neighborhood of St. Michael the Archangel's church in the $13^{\text {th }}$ century, 2) implementation of municipal law and the creation of new urban layout by Ladislaus the Elbow-High and Casimir the Great, 3) rapid acceleration of institutional and spatial development after Casimir's death.

Keywords: colonization; location; municipal government; town hall; urban chancery; urban layout; urbanization

The apparent acceleration of urban development throughout the whole $13^{\text {th }}$ century Latin Europe fostered the emergence of a new town-model in Polish lands. In contrary to many previously existing market-settlements, a "modern" municipal community constituted a particular administrative entity and a separate territorial unit with defined boundaries ${ }^{1}$. Given definition derives from

1 B. Zientara, Przemiany społeczno-gospodarcze i przestrzenne miast $w$ dobie lokacji, [in:] Miasta doby feudalnej w Europie środkowo-wschodniej. Przemiany społeczne a uktady przestrzenne, 
the $19^{\text {th }}$-century theoretical discussions, fixed within Max Weber's famous concept of "Western-European" or "occidental" town". The distinctive way of life shared by the citizens of occidental towns is considered to play an essential role in the establishment of today's Western-European model of civilization, funded upon capitalism, republicanism, and the concepts of civil rights. Weber's theory received much attention among sociologists, urbanists, and historians ${ }^{3}$. In the field of Polish urban historiography, influenced for a long time rather by Marxist approach, it was applied by Benedykt Zientara, who demonstrated the complexity of social, economic, and spatial transformations of Polish urban-landscape throughout the $13^{\text {th }}$ century ${ }^{4}$. In the following paper, I attempt to sketch an overview of similar changes, that resulted in establishing spatial frames and institutional structures of a Western-type municipal community in the $13^{\text {th }}$ - and $14^{\text {th }}$-century Lublin. The history of urban settlement on Lublin's Old Town Hill has been a subject of an on-going research at least since the interwar period. Systematic studies were initiated by scholars gathered within the newly erected local branch of Polish Historical Society, and then carried on after the World War II ${ }^{5}$. In 1965 the first volume of Lublin's historical monograph was published $^{6}$, and two years later a 650 -year anniversary of granting municipal rights to Lublin was celebrated with another joint publication ${ }^{7}$. The history of Lublin's self-governmental institutions was made a subject of detailed research for the first time by Zofia Froehlichowa ${ }^{8}$, while in the $2^{\text {nd }}$ half of the $20^{\text {th }}$ century the main stages of Lublin's spatial, economic, and institutional development were again carefully examined by Kazimierz Myśliński. Obviously, some of these findings have become outdated in the result of archaeological excavations,

red. A. Gieysztor, T. Rosłanowski, Warszawa 1976, pp. 67-97; idem, Przełom w rozwoju miast środkowoeuropejskich w pierwszej połowie XIII wieku, „Przegląd Historyczny” 1976, nr 67, pp. 219-243; S. Gawlas, Przełom lokacyjny w dziejach miast środkowoeuropejskich, [in:] Civitas Posnaniensis. Studia z dziejów średniowiecznego Poznania, red. Z. Kurnatowska, T. Jurek, Poznań 2005, pp. 133-162.

2 M. Weber, Die Stadt, „Archiv für Sozialwissenschaft und Sozialpolitik“ 1921, Bd. 47, pp. 621-772.

3 More on this subject: F. Irsigler, Annäherungen an den Stadtbegriff, [in:] Europäische Städte im Mittelalter, hrsg. v. F. Opll, Ch.P. Sonnlechner, Innsbruck 2010, pp. 15-30.

4 B. Zientara, Przemiany spoteczno-gospodarcze..., pp. 68-69.

5 J. Dobrzański, Oddziat Polskiego Towarzystwa Historycznego w Lublinie, „Rocznik Lubelski" 1958, nr 1, pp. 256-269.

6 Dzieje Lublina. Próba syntezy, red. J. Mazurkiewicz, t. 1, Lublin 1965.

Lublin 1317-1967, red. H. Zins, Lublin 1967.

8 Z. Froehlichowa, Z dziejów organizacji władz miejskich m. Lublina do końca XVII wieku, „Pamiętnik Lubelski” 1930, nr 1, pp. 69-115.

9 K. Myśliński, Wójt dziedziczny i rada miejska w Lublinie 1317-1504, Lublin 1962; idem, Czasy walki o samorzad, [in:] Dzieje Lublina..., pp. 57-79; idem, Najstarszy Lublin. Proces tworzenia się średniowieczne miasta, „Rocznik Lubelski” 1966, nr 9, pp. 145-188. 
initiated in Lublin in the 70 's ${ }^{10}$. Despite that, many aspects of Lublin's $13^{\text {th }}$ and $14^{\text {th }}$-century urban development are still difficult to clarify due to a severe shortage of written and material sources. Very small part of medieval municipal documentation from Lublin survived the numerous fires and have been taken over by the state archive in the $19^{\text {th }}$ century ${ }^{11}$, and only a few of the preserved documents were prepared and written down in the urban chancery ${ }^{12}$.

Until the unification of the Polish lands under the rule of Ladislaus the Elbow-High (1306-1333) and the inception of Polish military expansion towards the previous territories of the Duchy of Galicia-Volhynia by his son, Casimir the Great (1333-1370), lands of the future Lublin Voivodeship constituted a remote, sparsely-populated margins of the Duchy of Sandomierz ${ }^{13}$. Few local market-settlements lied beyond any visible influences of Western-European patterns of municipal development ${ }^{14}$. The essential core of the late-medieval settlementcomplex in Lublin developed throughout the $12^{\text {th }}$ and $13^{\text {th }}$ centuries, on a wide floodplain stretching in the bifurcation of the Czechówka and Bystrzyca river valleys. It consisted then of three separate units: the stronghold on the Castle-Hill, the marketplace by the St. Nicolas Church on the Czwartek-Hill, and the early-urban settlement on the Old Town-Hill - a nucleus of the later communal

${ }^{10}$ I. Kutyłowska, Rozwój Lublina w V-XIV wieku na tle urbanizacji międzyrzecza środkowej Wisty i Bugu, Lublin 1990; A. Rozwałka, Lubelskie wzgórze staromiejskie w procesie formowania średniowiecznego miasta, Lublin 1997; idem, Zarys stanu badań archeologicznych i historycznych średniowiecznego Lublina, [in:] Lublin przez wieki. Szkice z badań archeologicznych, red. E. Banasiewicz-Szykuła, Lublin 2004, pp. 35-52; A. Rozwałka, R. Niedźwiadek, M. Stasiak, Lublin wczesnośredniowieczny. Studium rozwoju przestrzennego, Warszawa 2006.

11 T. Mencel, Archiwum Akt Dawnych w Lublinie (1827-1887), „Rocznik Lubelski” 1958, nr 1, pp. 8-36; H. Gawarecki, S. Paulowa, M. Stankowa, Klęski pożarów w Lublinie, „Rocznik Lubelski" 1973, nr 16, pp. 211-225.

${ }_{12}$ M. Stankowa, Kancelaria miasta Lublina XIV-XVIII w., Warszawa 1968; M. Trojanowska, Dokument miejski lubelski od XIV do XVIII wieku. Studium dyplomatyczne, Warszawa 1977; M. Resztak, Ze studiów nad kulturą prawną kancelarii miejskiej późnośredniowiecznego Lublina, [in:] Coram iudicio. Studia z dziejów kultury prawnej w miastach późnośredniowiecznej Polski, red. A. Bartoszewicz, Warszawa 2013, pp. 109-130.

${ }^{13}$ K. Myśliński, Geneza dawnego województwa lubelskiego, [in:] Spojrzenia w przeszłość Lubelszczyzny, red. K. Myśliński, A.A. Witusik, Lublin 1974, pp. 9-25; A. Sochacka, Polityczne i administracyjne zwiazki terytorium lubelskiego z Sandomierzem w średniowieczu, [in:] Sandomierz - z dziejów polityki, prawa i kultury, red. A. Wrzyszcz, Sandomierz 2001, pp. 74-88; A. Teterycz-Puzio, Geneza województwa sandomierskiego. Terytorium i miejsce w strukturze państwa polskiego w średniowieczu, Słupsk 2001, pp. 99-100.

${ }^{14}$ K. Myśliński, Najstarsza miejska historia Lubelszczyzny w świetle dokumentu Konrada Mazowieckiego z roku około 1239, [in:] Studia historyczne. Ksiega Jubileuszowa z okazji 70. rocznicy urodzin prof. dra Stanistawa Arnolda, Warszawa 1965, pp. 288-300; idem, Poczatki miast na obszarze między Wista środkowa i Bugiem, [in:] I Międzynarodowy Kongres Archeologii Stowiańskiej, Warszawa 14-18 IX 1965, red. W. Hensel, t. 4, Wrocław 1968, pp. 337-349; I. Kutyłowska, Miasta Lubelszczyzny sprzed układu w Krewie (stan badań), [in:] Civitas et villa. Miasto i wieś w średniowiecznej Europie Środkowej, red. C. Buśko, Wrocław 2002, pp. 165-175. 
town ${ }^{15}$. Already in the $13^{\text {th }}$ century, besides being an important local and long-distance trade stop, Lublin fulfilled substantial political and ecclesiasticalcentral-functions. It served as a centre of a ducal administration unit, the castellany of Lublin ${ }^{16}$, and was a seat to the archdeacon, whose hereditary estate stretched alongside the eastern rim of the Old Town-Hill ${ }^{17}$.

An apparent acceleration of urban transformations leading to the establishment of a Western-type urban community on the Old Town-Hill in Lublin took place in the $2^{\text {nd }}$ half of the $13^{\text {th }}$ century. It was marked by the emergence of ecclesiastical foundations and institutions considered typical to late-medieval urban settlements. Probably between 1264 and 1272 the duke Boleslaus the Chaste (1243-1279) founded the first Dominican monastery in Lublin $^{18}$. The convent was placed on the eastern border of the densely settled area, suiting the general model of localization of mendicant monasteries in urban space by that time. Probably around 1282 Boleslaus' successor, Lestco the Black (1279-1288) founded the parochial church dedicated to St. Michael the Archange ${ }^{19}$. It lied within the hereditary estate of Lublin's archdeacons by today's Grodzka Street - the main axis of an early-urban settlement. The southern urban border was demarcated by an early medieval gully along

15 A. Rozwałka, R. Niedźwiadek, M. Stasiak, op. cit., pp. 104-110.

16 The first castellan was mentioned in 1227: Kodeks dyplomatyczny Małopolski, red. F. Piekosiński, t. 1, Kraków 1876, nr 10. See also: K. Myśliński, Najstarszy Lublin ..., p. 163; Urzędnicy matopolscy XII-XV wieku: spisy, red. J. Kurtyka, Wrocław 1990.

17 The first archdeacon was mentioned in 1198: Kodeks dyplomatyczny Małopolski, red. F. Piekosiński, t. 2, Kraków 1886, nr 376. See also: P. Szafran, Rozwój średniowiecznej sieci parafialnej w Lubelskiem, Lublin 1958, pp. 35-49; A. Rozwałka, Sieć osadnicza w archidiakonacie lubelskim w średniowieczu. Studium archeologiczno-historyczne, Lublin 1999.

18 The monastery was mentioned for the first time in a list of Dominican convents composed in 1304 by Bernhard Gui: J. Kłoczowski, Dominikanie polscy na Śląsku w XIII-XIV wieku, Lublin 1956, pp. 288-289. See also: idem, Najstarszy klasztor lubelski i jego poczatkowe dzieje, [in:] Kościót, społeczeństwo, kultura. Prace ofiarowane profesorowi Wiesławowi Müllerowi z okazji pięćdziesięciolecia pracy naukowej i dydaktycznej, red. J. Drob, Lublin 2004, pp. 11-16; idem, Klasztor dominikański w Lublinie w pierwszych wiekach swego istnienia w ramach prowincji polskiej (stulecia XIII-XVI), [in:] Dominikanie w Lublinie. Studia z dziejów kultury, red. H. Gapski, Lublin 2006, pp. 23-58; A. Rozwałka, M. Stasiak, Dominikanie a przestrzeń miejska średniowiecznego Lublina, [in:] Dominikanie w Lublinie..., pp. 59-71.

19 The church was mentioned for the first time in the $14^{\text {th }}$ century. The conviction of a an older foundation was expressed by Jan Długosz (Liber beneficiorum diocesis cracoviensis, t. 2, „Opera omnia”, 8, Kraków 1864, p. 536), who based upon a local tradition, partially documented by older annalas: P. Żmudzki, Studium podzielonego Królestwa. Książe Leszek Czarny, Warszawa 2000, pp. 300-301; J. Kuczyńska, Kościół farny św. Michała w Lublinie, Lublin 2004, pp. 43-44; W. Michalski, Two Medieval Traditions of Lublin and Their Influence on the Local Community's Sense of Identity (13 ${ }^{\text {th }}$ ? - the Beginning of the $17^{\text {th }}$ Century) [in print]. See also: E. Mitrus, Poczatki kościoła św. Michała w Lublinie, [in:] Lublin przez wieki..., pp. 53-80; A. Rozwałka, R. Niedźwiadek, M. Stasiak, op. cit., pp. 163-170. 
today's Rybna and Złota Streets ${ }^{20}$. The layout based upon a market street is seen as typical to rural and urban settlements existing in the Polish lands before the adaptation of Magdeburg-municipal law and the delimitation of the first "chessboard-layouts" with rectangular market squares around the mid-13 ${ }^{\text {th }}$ century $^{21}$. Therefore it seems unlikely that the settlement on Lublin's Old Town-Hill could constitute already a separate, autonomous community with a precisely shaped urban layout and a municipal organization, approved by an unknown location charter 22 . It also needs to be stressed, that the urban development in Lublin was constantly hindered by Prussian, Tatar and Ruthenian incursions ${ }^{23}$. In times of political turmoils in Lesser Poland after Lestco's childless death in 1288, Lublin was even temporarily incorporated to the Duchy of GaliciaVolhynia and then taken back by the Polish forces in $1306^{24}$. The anonymous

20 S. Michalczuk, O początkach Lublina, czyli geneza układu urbanistycznego Starego Miasta, „Biuletyn Historii Sztuki” 1970, nr 2, pp. 206-209; I. Kutyłowska, Wczesnośredniowieczne umocnienia obronne na wzgórzu staromiejskim w Lublinie, „Rocznik Lubelski” 1983-1984, nr 25-26, pp. 173-180; eadem, Rozwój Lublina ..., pp. 147-148; R. Szczygieł, Zmiany centrum handlowego Lublina od XIV do XVII wieku, „Kwartalnik Historii Kultury Materialnej” 1992, nr 3, pp. 313-318; A. Rozwałka, R. Niedźwiadek, M. Stasiak, op. cit., pp. 135-163.

${ }^{21}$ S. Gawlas, Ulica a zmiany krajobrazu miejskiego w okresie lokacji, „Kwartalnik Historii Kultury Materialnej” 1000, nr 1-2, pp. 3-25; idem, Przetom lokacyjny..., pp. 150-154; idem, Ustrojowe i społeczne uwarunkowania lokacji miejskich na ziemiach polskich $w 1$. polowie XIII wieku, „Archaeologia Historica Polona” 2015, nr 23, pp. 7-56.

${ }_{22}$ Such assumption has been made by J. Riabinin (Materiaty do historii miasta Lublina 1317-1792, Lublin 1938, p. VII), who discovered, that according to $17^{\text {th }}$-century royal lustrations burgers believed in the existance of an older, original location charter, which went missing during an unspecified Tatar. The concept of $13^{\text {th }}$-century location was articulated explicitly by W. Müller, Data lokacji Lublina, „Roczniki Humanistyczne” 1960, nr 4, p. 101. The interpretation has been discredited by other historians: Z. Sułowski, Przedlokacyjny Lublin w świetle źródet pisanych, [in:] Dzieje Lublina ..., p. 40; J. Kłoczowski, Lublin po nadaniu prawa miejskiego, [in:] Dzieje Lublina ..., p. 50; K. Myśliński, Najstarszy Lublin ..., pp. 179-181. Despite that, Müller's theory was accepted in archeological studies: I. Kutyłowska, Rozwój Lublina ..., p. 157; A. Rozwałka, Lubelskie wzgórze ..., pp. 74-79; A. Rozwałka, R. Niedźwiadek, M. Stasiak, op. cit., pp. 135-148. It was also adapted by R. Szczygieł, Wokót lokacji Lublina na prawie niemieckim, [in:] Hereditas praeteriti additamenta archaeologica et historica dedicata Ioanni Gurba Octogesimo Anno Nascendi, red. H. Taras, A. Zakościelna, Lublin 2009, pp. 501-508. Same author, however, withdrew from this position, undermining the credibility of the tradition fixed in royal lustrations: idem, Lokacja i rozwój Lublina w XIV w. Na drodze ku świetności [in print].

${ }^{23}$ S. Krakowski, Polska $w$ walce z najazdami tatarskimi w XIII wieku, Warszawa 1956; K. Myśliński, Problemy terytorialne w stosunkach między Polska i księstwem halicko-włodzimierskim w XIII wieku, [in:] Nihil superfluum esse. Prace z dziejów średniowiecza ofiarowane Profesor Jadwidze Krzyżaniakowej, red. J. Strzelczyk, J. Dobosz, Poznań 2000, pp. 229-236; A. Teterycz-Puzio, Przyczyny i cele najazdów litewskich na ziemię sandomierska w XIII w., „Rocznik Lubelski” 2009, nr 35, pp. 9-22.

${ }_{24}$ The chronology of events was recently discussed by K. Myśliński, Problemy terytorialne..., p. 235; A. Teterycz-Puzio, Przyczyny i cele najazdów..., pp. 20-21; A. Rozwałka, R. Niedźwiadek, M. Stasiak, op. cit., p. 145. 
contemporary historiographical description of that intervention names the urban settlement on the Old Town-Hill remarkably "the new Lublin (Lublin novum), that the Ruthenians occupied for many years (quod Rutheni occupaverunt pluribus annis)" 25 .

Shortly after, the gradual development of urban structures in Lublin was encouraged by Ladislaus the Elbow-High, who issued the Lublin's location charter on 15 August $1317^{26}$. It is addressed to the first hereditary vogt (advocatus) of Lublin, Maciej of Opatowiec, a wealthy burger from Cracow and an influential functionary of the ducal economic administration ${ }^{27}$. According to the $16^{\text {th }}$-century dorsal note, originally the charter was a personal belonging of the vogts. After the abolishment of their office in 1548, it was given to the municipal authorities ${ }^{28}$. The document, composed with a use of a rather untypical formulary, is very laconic ${ }^{29}$. It's first part contains a detailed description of the hereditary property belonging to the vogts. They received every sixth fief of land, the third part of court fees, the whole income from butchers', bakers', and shoemakers' stores, all taverns, every sixth cloth store and booth, slaughterhouse, baths, the right to build an unlimited number of mills, and the right to organize a private fish pond. Rest of regulations included the implementation of Magdeburg municipal law, the demarcation of 100 fiefs of rural fields and some pastoral fields belonging to the town, the granting of a 20-years liberation from rent and any other non-monetary obligations as well as the perpetual liberation from customs duty throughout the whole state ${ }^{30}$.

The chessboard-layout with a centrally situated rectangular market-square had to be however organized away from the still existing hereditary estate of archdeacons on the Old Town-Hill. It was demarcated in the South, on the other side of the early medieval gully, that divided the new urban area from

${ }_{25}$ E.g. Traska Annals: Monumenta Poloniae Historica, t. 2, Lwów 1872, p. 853: inierunt milites Cracovienses et Sandomirienses Russiam, videlicet Lublin novum, quod Rutheni occupaverunt pluribus annis, expugnaverunt, deinde in paucis cum multitudine Ruthenorum et Lithwanorum ac Tartharorum pugnaverunt, et Domino cooperante de omnibus triumphaverunt. Postea reversi ipsum castrum Lublin optinuerunt.

${ }^{26}$ The best edition so-far has been accomplished by J. Szymański, Dokument lokacyjny Władystawa Lokietka dla Lublina z 1317 roku, [in:] Lublin 1317-1967, pp. 282-287. See also: Z. Froehlichowa, op. cit., pp. 76-77; K. Myśliński, Wójt dziedziczny..., pp. 13-14.

27 J. Ptaśnik, Studia nad patrycjatem krakowskim wieków średnich, „Rocznik Krakowski” 1913, nr 15, p. 73; J. Wyrozumski, Maciej, [w:] Polski stownik biograficzny, red. E. Rostworowski, t. 19, Wrocław 1974, p. 7; Urzędnicy matopolscy XII-XV wieku, nr 1417.

28 J. Szymański, op. cit., p. 283: Franconi de Mognicia, prz[edał] Peczynowi, prz[edał] Morsztynowi, successores Morstina miastu cum consensu J[ego] K[rólewskiej] M[oś]ci miastu advocatiam przedali, incorporatio per constitutionem 15[48].

${ }^{29}$ Ibidem, pp. 269-287. See also: S. Kuraś, Przywileje prawa niemieckiego miast i wsi małopolskich XIV-XV wieku, Wrocław 1971, p. 109.

${ }^{30}$ R. Szczygieł, Wokót lokacji Lublina ..., pp. 506-507. 
the $13^{\text {th }}$-century urban-settlement along the market street ${ }^{31}$. The definitive unification of urban space on the Old Town-Hill in Lublin has been accomplished under the rule of the next king, Casimir the Great, who pursued a modern urban and economic policy ${ }^{32}$. He also initiated a successful military conquest of the Galicia-Volhynia Rus'. Shortly after, Lublin was promoted to the role of the main stop on the long-distance trade routs connecting Pomerania and Silesia with the Black Sea region ${ }^{33}$. In 1342, after the last-year Ruthenian invasion, Casimir sold the office of Lublin's hereditary vogt to Franczko (Francis) of Mainz and reformed the original location charter from $1317^{34}$. The king granted him two hereditary suburban villages, Bronowice and Konopnica, the whole income from every commercial stall in Lublin, as well as the right to distribute wood within the town borders ${ }^{35}$. According to a panegyric description of Casimir's rule in the $14^{\text {th }}$ century Kraków Cathedral Chronicle, the king was responsible for the construction of the town walls in Lublin, while Jan Długosz added in his Annales, that Casimir built a castle on the place of the wooden stronghold on the Castle-Hill ${ }^{36}$. From Długosz's Liber Beneficiorum we also learn, that Casimir remodeled spatial conditions within the town walls. He founded a new Dominican monastery, situated "next to the town walls" (circa muros oppidi) $)^{37}$, and incorporated the hereditary property of archdeacons to the urban estate in exchange for a suburban

${ }^{31}$ Recently: A. Rozwałka, R. Niedźwiadek, M. Stasiak, op. cit., pp. 153-163.

32 S. Gawlas, Uwagi o polityce miejskiej Kazimierza Wielkiego, [in:] Aetas media, aetas moderna. Studia ofiarowane profesorowi Henrykowi Samsonowiczowi w siedemdziesiata rocznice urodzin, red. H. Manikowska, A. Bartoszewicz, W. Fałkowski, Warszawa 2000, pp. 25-41.

${ }^{33}$ K. Myśliński, Lublin a handel Wrocławia z Rusia w XIV i XV wieku, „Rocznik Lubelski” 1960, nr 3, pp. 5-36; idem, Lublin w życiu gospodarczym i politycznym Polski przedrozbiorowej, [in:] Lublin 1317-1967, pp. 20-24. See also: H. Samsonowicz, Przemiany osi drożnych w Polsce późnego średniowiecza, „Przegląd Historyczny” 1973, nr 64, pp. 697-716; idem, Szlak baltycko-czarnomorski w XIII-XIV wieku, [in:] Balticum. Studia z dziejów polityki, gospodarki i kultury XIIXVII wieku ofiarowane Marianowi Biskupowi w siedemdziesiąta rocznicę urodzin, red. Z.H. Nowak, Torun 1992, pp. 285-290; A. Orłowska, W sprawie polityki handlowej Kazimierza Wielkiego, [in:] Z dziejów średniowiecznej Europy Środkowo-Wschodniej. Zbiór studiów, red. J. Tyszkiewicz, cz. 2, Warszawa 2007, pp. 153-165.

${ }^{34}$ Kodeks dyplomatyczny Małopolski, red. F. Piekosiński, t. 3, Kraków 1887, No. 668; Z. Froehlichowa, op. cit., p. 78; K. Myśliński, Wójt dziedziczny..., pp. 14-15.

35 Słownik historyczno-geograficzny województwa lubelskiego w średniowieczu, t. 3: Dzieje Lubelszczyzny, oprac. S. Kuraś, Warszawa 1983, pp. 39, 107; A. Rola, Historia podlubelskiej wsi Konopnica do połowy XVI wieku, „Rocznik Lubelski” 2013, nr 39, p. 11.

${ }_{36}$ Monumenta Poloniae Historica, red. A. Bielowski, t. 2, Lwów 1872, p. 625; J. Długosz, Annales seu Cronicae incliti Regni Poloniae, lib. 9, red. D. Turkowska, Warszawa 1987, p. 349; J. Widawski, Miejskie mury obronne w państwie polskim do poczatku XV wieku, Warszawa 1973, pp. 250, 255-256; E. Mitrus, Archeologia o murach miejskich i młodszych liniach obrony miasta, [in:] Lublin i okolice w badaniach archeologicznych, red. E. Banasiewicz, Lublin 1999, pp. 31-38.

37 J. Długosz, Liber beneficiorum, t. 3, p. 459. 
valley Dziesiąta (later Sokolniki) ${ }^{38}$. However, the Church made efforts to take its former possessions back still in the $15^{\text {th }}$ and $16^{\text {th }}$ centuries $^{39}$. The incorporated property consisted of a "one whole street" (una platea integra), that linked the parochial church to the Dominican monastery. Presumably, around this time, the old gully along the today's Rybna and Złota Streets was also filled ${ }^{40}$. A similar sequence of spatial regulations occurred not too far away, in Sandomierz ${ }^{41}$. Casimir extended towns' borders, delimited in 1286 by Lestco the Black on the Town-Hill, and surrounded it with the stone walls. The expanding urban settlement absorbed the ecclesiastical estate on the Cathedral-Hill, and the deep gully dividing both hills was filled. That operation provoked a series of proprietary disputes between the burgers and the collegiate church after Casimir's death. The incorporation of ecclesiastical property into the expanding estate of municipal town in Płock resulted in identical conflicts ${ }^{42}$.

Despite the evident reinforcement of Lublin's spatial and economic development, the series of reforms introduced by Casimir did not result in an instant establishment of a fully developed communal government. Casimir's consistent urban policy was aimed rather at strengthening king's control over his subjects and multiplying royal financial incomes ${ }^{43}$. The well-documented actions of royal dignitaries against the burghers of Cracow reflect a strong conviction of their supremacy over municipal institutions ${ }^{44}$. The already mentioned document issued by the king in 1342 supported the economic and political domination of hereditary vogts over Lublin's burgers. Besides that, royal interests in town were also defended by the general starosta (capitaneus Lublinensis et dominus generalis terrae Lublinensis), whose office was erected by Casimir before $1359^{45}$. The significant weakness of municipal structures in Lublin in this period is clearly reflected in a document of the third known hereditary vogt, Laurentius, in 1360. Although it concerned

38 Ibidem, t. 1, p. 198; Stownik historyczno-geograficzny, p. 70.

39 I. Kutyłowska, Rozwój Lublina ..., p. 94; A. Rozwałka, Lubelskie wzgórze..., p. 83; idem, Sieć osadnicza..., p. 26.

40 I. Kutyłowska, Wczesnośredniowieczne umocnienia..., pp. 179-180; eadem, Rozwój Lublina ..., pp. 164-165; A. Rozwałka, Lubelskie wzgórze..., p. 79.

${ }^{41}$ P. Okniński, Główne etapy kształtowania się miasta lokacyjnego w Sandomierzu w XIIIXIV wieku, „Roczniki Historyczne” 2016, nr 82, pp. 94-98.

42 S.M. Szacherska, Płock - civitas vetus czy civitas cathedralis?, [in:] Społeczeństwo Polski średniowiecznej, red. S.K. Kuczyński, t. 5, Warszawa 1992, pp. 186-187.

43 S. Gawlas, Uwagi o polityce miejskiej..., p. 36.

44 M. Starzyński, Spór o miasto. Kraków w ostatnim dziesięcioleciu panowania Kazimierza Wielkiego, [in:] Kazimierz - sławny i z czynów wielki, red. M. Starzyński, Kraków 2011, pp. 85-95.

${ }_{45}$ Zbiór dokumentów małopolskich, red. S. Kuraś, t. 4, Wrocław 1969, nr 961; K. Myśliński, Geneza dawnego województwa..., p. 13; A. Sochacka, Organizacja zarządu dóbr ziemskich $w$ województwie lubelskim w średniowieczu, „Rocznik Lubelski” 1985-1986, nr 27-28, p. 36; eadem, Polityczne i administracyjne zwiąki..., pp. 85-86; Urzędnicy małopolscy XII-XV wieku, nr 1304. 
a transaction approved during the session of scabinal court (in bannito iudicio), it was issued independently by the vogt and sealed exclusively with his own seal, named sigillum nostrum ${ }^{46}$. It comes as no surprise, that the first signs of struggles for political autonomy in Lublin appeared shortly after the death of Casimir in $1370^{47}$. Burgers' aspirations manifested themselves in a conflict with the starosta Peter of Szczekociny ${ }^{48}$. In 1377 Elisabeth of Poland, the Polish regent and a former queen of Hungary, renewed all liberties (libertates, consuetudines atque iura) granted to Lublin by Ladislaus and Casimir and reminded Peter not to break them ${ }^{49}$. Two years later Peter pledged to obey the privileges (iura et constituciones omnia civium et tocius communitatis civitatis Lublinensis), and to amend all the damage he had done to the burgers (astringimus nos eisdem civibus predicte civitatis ad satisfaciendum pro ipsorum iniuriis per nos eis illatis) ${ }^{50}$. Around that time Lublin's hereditary vogts were deprived of village Konopnica, granted to them by Casimir in 1342. In 1386 it was given by the king Ladislaus Jagiello (1386-1434) to the next starosta, Włodek (Ladislaus) of Charbinowice, who sold it to the town 14 years later ${ }^{51}$.

The temporal weakness of royal authority over Lublin after the death of the last crowned Piast fostered also the establishment of the most significant municipal institution, the town council, traditionally opposed to the hereditary vogt and starosta ${ }^{52}$. It was mentioned for the first time in 1377 when Peter of Szczekociny liberated two urban fiefs from the annual rent on king's behalf. According to his words, such request has been made by the town councilors of Lublin: sagaces et providi vires consules civitatis Lublinensis ${ }^{53}$. The document issued by the town council in 1396 contains the oldest mention on burgermeister (prior civitatis) $)^{54}$. As usual, the establishment of municipal authorities was followed by the gradual emergence of urban chancery and archive ${ }^{55}$. According to

46 Zbiór dokumentów małopolskich, t, 4, nr 965; M. Stankowa, op. cit., p. 36; M. Trojanowska, Pieczęcie miasta Lublina od roku 1317 do roku 1811, „Archeion” 1974, nr 60-61, pp. 84-85; P. Dymmel, System sfragistyczny średniowiecznego Lublina. Próba rekonstrukcji, [in:] Pieczęć w Polsce średniowiecznej i nowożytnej. Zbiór studiów, red. P. Dymmel, Lublin 1998, pp. 196-197.

${ }^{47}$ K. Myśliński, Wójt dziedziczny..., pp. 27-28.

48 Urzędnicy matopolscy XII-XV wieku, $\mathrm{nr} 1306$.

49 Kodeks dyplomatyczny Małopolski, t. 3, nr 888.

${ }^{50}$ Ibidem, nr 911.

${ }^{51}$ Materiaty do historii miasta Lublina 1317-1792, red. J. Riabinin, Lublin 1938, nr 14; Stownik historyczno-geograficzny..., p. 107; Urzędnicy małopolscy XII-XV w., nr 1307; A. Rola, op. cit., pp. 12-13.

${ }^{52}$ K. Myśliński, Wójt dziedziczny..., pp. 19-29. More on this subject: A. Gąsiorowski, Wójt i starosta. Ramię monarsze w polskim mieście średniowiecznym, [in:] Ars historica. Prace z dziejów powszechnych i Polski, red. M. Biskup, Poznań 1976, pp. 437-444.

${ }_{53}$ Kodeks dyplomatyczny Małopolski, t. 3, nr 894.

${ }_{54}$ Materiaty do historii miasta Lublina, nr 13, p. 6.

55 P. Okniński, Uwarunkowania początków rozwoju polskich kancelarii miejskich na przykładzie Krakowa (do 1312 r.), [in:] Loca scribendi. Miejsca i środowiska tworzace kulturę pisma 
the corroboration formulas in two other documents from 1396, the first one was protected with the main town seal, at the disposal of the town council (sigillum consulum), while the second one was stamped with a different seal, belonging to the scabines (sigillum scabinorum) ${ }^{56}$. Although the oldest preserved book of records from Lublin was established only in $1465^{57}$, there are solid grounds to assume, that an older volume was in use already at in 1396 and then got lost in the fire ${ }^{58}$. The second oldest acknowledged manuscript of this type was also lost, its fragments, however, reaching 1405 , have been printed in the $2^{\text {nd }}$ half of the $19^{\text {th }}$ century ${ }^{59}$. At the beginning of the $15^{\text {th }}$ century, the municipal authorities of Lublin had also a fixed seat. Their town hall, named praetorium, was mentioned in a statute published by the town council in $1419^{60}$.

Taking this all into consideration it should be emphasized, that the establishment of a municipal community in Lublin should not be seen as a simple result of a decision approved by a single location charter, but rather as a complex, multifaceted process. It accelerated noticeably in the $13^{\text {th }}$ century, in the period of the intensified Polish urbanization, and then proceeded in dynamically changing political and economic circumstances, being encouraged by succeeding rulers, with different political goals and capabilities. The general outlines of spatial and institutional framework typical to a communal town were shaped until the turn of the $14^{\text {th }}$ and $15^{\text {th }}$ centuries.

w dawnej Rzeczypospolitej XV-XVIII stulecia, red. A. Adamska, A. Bartoszewicz, M. Ptaszyński, Warszawa 2012, pp. 27-45.

${ }^{56}$ Zbiór dokumentów małopolskich, t. 4, nr 1125-1126; M. Stankowa, op. cit., p. 36; M. Trojanowska, Pieczęcie miasta Lublina ..., p. 85; eadem, Katalog pieczęci miasta Lublina od roku 1317 do roku 1811, „Archeion” 1974, nr 60-61, pp. 105-106; P. Dymmel, op. cit., p. 200.

${ }^{57}$ M. Resztak, Najstarsza zachowana lubelska księga miejska i jej pisarze, cz. 1, „Studia Źródłoznawcze" 2013, nr 51, pp. 3-18; idem, Najstarsza zachowana lubelska księga miejska i jej pisarze, cz. 2, „Studia Źródłoznawcze” 2014, nr 52, pp. 23-43.

${ }^{58}$ Materiały do historii miasta Lublina, p. XII; Zbiór dokumentów małopolskich, red. S. Kuraś, t. 5, Wrocław 1970, nr 1125.

59 Wyjątki z najdawniejszej księgi miejskiej lubelskiej, [in:] Archiwum Komisji Historycznej, t. 3, Kraków 1886, pp. 45-60; M. Stankowa, op. cit., p. 36; M. Trojanowska, Dokument miejski lubelski od XIV do XVIII wieku..., p. 87; M. Resztak, Najstarsza zachowana lubelska księga, p. 5.

${ }^{60}$ Wilkierze $X V-X V I I$ w., red. L. Białkowski, Lublin 1928, nr 2. However, yet in 1408 the town councilors held an official meeting in a home belonging to a private burger - Wilkierze $X V-X V I I$ w., nr 1: Actum in domo parve Michaelis in die s. Mariae Magdalenae. See: K. Myśliński, Wójt dziedziczny..., pp. 43-44. For similar cases see: A. Bartoszewicz, Ratusz w matych miastach polskich w XV-XVI wieku, „Roczniki Dziejów Społecznych i Gospodarczych” 2014, nr 74, pp. 161-172. 


\section{REFERENCES}

\section{Sources}

Długosz J., Annales seu Cronicae incliti Regni Poloniae, lib. 9, red. D. Turkowska, Warszawa 1987.

Długosz J., Liber beneficiorum diocesis cracoviensis, t. 1-3, „Opera omnia”, 7-9, Kraków $1863-1864$.

Kodeks dyplomatyczny małopolski, red. F. Piekosiński, t. 1-3, Kraków 1876, 1886, 1887.

Materiaty do historii miasta Lublina 1317-1792, red. J. Riabinin, Lublin 1938.

Monumenta Poloniae Historica, red. A. Bielowski, t. 2, Lwów 1872.

Traska Annals: Monumenta Poloniae Historica, t. 2, Lwów 1872.

Wilkierze XV-XVII w., red. L. Białkowski, Lublin 1928.

Wyjątki z najdawniejszej księgi miejskiej lubelskiej, [in:] Archiwum Komisji Historycznej, t. 3, Kraków 1886.

Zbiór dokumentów matopolskich, red. S. Kuraś, t. 4-5, Wrocław 1969, 1970.

\section{Literature}

Bartoszewicz A., Ratusz w matych miastach polskich w XV-XVI wieku, „Roczniki Dziejów Społecznych i Gospodarczych" 2014, nr 74, pp. 161-172.

Dobrzański J., Oddzial Polskiego Towarzystwa Historycznego w Lublinie, „Rocznik Lubelski” 1958, nr 1, pp. 256-269.

Drelicharz W., Annalistyka małopolska XIII-XV wieku: kierunki rozwoju wielkich roczników kompilowanych, Kraków 2003.

Dymmel P., System sfragistyczny średniowiecznego Lublina. Próba rekonstrukcji, [in:] Pieczęć w Polsce średniowiecznej i nowożytnej. Zbiór studiów, red. P. Dymmel, Lublin 1998, pp. 193-215.

Dzieje Lublina. Próba syntezy, red. J. Mazurkiewicz, t. 1, Lublin 1965.

Froehlichowa Z., Z dziejów organizacji władz miejskich m. Lublina do końca XVII wieku, „Pamiętnik Lubelski” 1930, nr 1, pp. 69-115.

Gawarecki H., Paulowa S., Stankowa M., Klęski pożarów w Lublinie, „Rocznik Lubelski” 1973, nr 16, pp. 211-225.

Gawlas S., Przetom lokacyjny $w$ dziejach miast środkowoeuropejskich, [in:] Civitas Posnaniensis. Studia z dziejów średniowiecznego Poznania, red. Z. Kurnatowska, T. Jurek, Poznań 2005, pp. 133-162.

Gawlas S., Ulica a zmiany krajobrazu miejskiego w okresie lokacji, „Kwartalnik Historii Kultury Materialnej" 1999, nr 1-2, pp. 3-25.

Gawlas S., Ustrojowe $i$ społeczne uwarunkowania lokacji miejskich na ziemiach polskich w 1. połowie XIII wieku, „Archaeologia Historica Polona” 2015, nr 23, pp. 7-56.

Gawlas S., Uwagi o polityce miejskiej Kazimierza Wielkiego, [in:] Aetas media, aetas moderna. Studia ofiarowane profesorowi Henrykowi Samsonowiczowi w siedemdziesiata rocznice urodzin, red. H. Manikowska, A. Bartoszewicz, W. Fałkowski, Warszawa 2000, pp. 25-41.

Gąsiorowski A., Wójt i starosta. Ramię monarsze w polskim mieście średniowiecznym, [in:] Ars historica. Prace z dziejów powszechnych i Polski, red. M. Biskup, Poznań 1976, pp. 437-444.

Irsigler F., Annäherungen an den Stadtbegriff, [in:] Europäische Städte im Mittelalter, hrsg. v. F. Opll, Ch.P. Sonnlechner, Innsbruck 2010, pp. 15-30.

Kłoczowski J., Dominikanie polscy na Ślasku w XIII-XIV wieku, Lublin 1956.

Kłoczowski J., Klasztor dominikański w Lublinie w pierwszych wiekach swego istnienia w ramach prowincji polskiej (stulecia XIII-XVI), [in:] Dominikanie w Lublinie. Studia z dziejów kultury, red. H. Gapski, Lublin 2006, pp. 23-58. 
Kłoczowski J., Lublin po nadaniu prawa miejskiego, [in:] Dzieje Lublina. Próba syntezy, red. J. Mazurkiewicz, t. 1, Lublin 1965, pp. 45-56.

Kłoczowski J., Najstarszy klasztor lubelski i jego początkowe dzieje, [in:] Kościót, społeczeństwo, kultura. Prace ofiarowane profesorowi Wiestawowi Müllerowi z okazji pięćdziesięciolecia pracy naukowej i dydaktycznej, red. J. Drob, Lublin 2004, pp. 11-16.

Krakowski S., Polska w walce z najazdami tatarskimi w XIII wieku, Warszawa 1956.

Kuczyńska J., Kościót farny św. Michała w Lublinie, Lublin 2004.

Kuraś S., Przywileje prawa niemieckiego miast $i$ wsi małopolskich XIV-XV wieku, Wrocław 1971.

Kutyłowska I., Miasta Lubelszczyzny sprzed układu w Krewie (stan badań), [in:] Civitas et villa. Miasto i wieś w średniowiecznej Europie Środkowej, red. C. Buśko, Wrocław 2002, pp. 165-175.

Kutyłowska I., Rozwój Lublina w V-XIV wieku na tle urbanizacji międzyrzecza środkowej Wisty i Bugu, Lublin 1990.

Kutyłowska I., Wczesnośredniowieczne umocnienia obronne na wzgórzu staromiejskim w Lublinie, „Rocznik Lubelski” 1983-1984, nr 25-26, pp. 173-180.

Lublin 1317-1967, red. H. Zins, Lublin 1967.

Mencel T., Archiwum Akt Dawnych w Lublinie (1827-1887), „Rocznik Lubelski” 1958, nr 1, pp. 8-36.

Michalczuk S., O poczatkach Lublina, czyli geneza układu urbanistycznego Starego Miasta, „Biuletyn Historii Sztuki” 1970, nr 2, pp. 206-209.

Michalski W., Two Medieval Traditions of Lublin and Their Influence on the Local Community's Sense of Identity (1 $3^{\text {th }}$ ? - the Beginning of the $17^{\text {th }}$ Century) [in print].

Mitrus E., Archeologia o murach miejskich i młodszych liniach obrony miasta, [in:] Lublin i okolice w badaniach archeologicznych, red. E. Banasiewicz, Lublin 1999, pp. 31-38.

Mitrus E., Początki kościoła św. Michała w Lublinie, [in:] Lublin przez wieki. Szkice z badań archeologicznych, red. E. Banasiewicz-Szykuła, Lublin 2004, pp. 53-80.

Müller W., Data lokacji Lublina, „Roczniki Humanistyczne” 1960, nr 4, pp. 101-107.

Myśliński K., Czasy walki o samorząd, [in:] Dzieje Lublina. Próba syntezy, red. J. Mazurkiewicz, t. 1, Lublin 1965, pp. 57-79.

Myśliński K., Geneza dawnego województwa lubelskiego, [in:] Spojrzenia w przeszłość Lubelszczyzny, red. K. Myśliński, A.A. Witusik, Lublin 1974, pp. 9-25.

Myśliński K., Lublin a handel Wroctawia z Rusia w XIV i XV wieku, „Rocznik Lubelski” 1960, nr 3, pp. 5-36.

Myśliński K., Lublin w życiu gospodarczym i politycznym Polski przedrozbiorowej, [in:] Lublin 1317-1967, red. H. Zins, Lublin 1967, pp. 7-48.

Myśliński K., Najstarsza miejska historia Lubelszczyzny $w$ świetle dokumentu Konrada Mazowieckiego z roku około 1239, [in:] Studia historyczne. Księga Jubileuszowa z okazji 70. rocznicy urodzin prof. dra Stanisława Arnolda, Warszawa 1965, pp. 288-300.

Myśliński K., Najstarszy Lublin. Proces tworzenia się średniowiecznego miasta, „Rocznik Lubelski” 1966, nr 9, pp. 145-188.

Myśliński K., Początki miast na obszarze między Wisła środkowa i Bugiem, [in:] I Międzynarodowy Kongres Archeologii Stowiańskiej, Warszawa 14-18 IX 1965, red. W. Hensel, t. 4, Wrocław 1968, pp. 337-349.

Myśliński K., Problemy terytorialne w stosunkach między Polską i księstwem halicko-włodzimierskim w XIII wieku, [in:] Nihil superfluum esse. Prace z dziejów średniowiecza ofiarowane Profesor Jadwidze Krzyżaniakowej, red. J. Strzelczyk, J. Dobosz, Poznań 2000, pp. 229-236.

Myśliński K., Wójt dziedziczny i rada miejska w Lublinie 1317-1504, Lublin 1962.

Okniński P., Gtówne etapy kształtowania się miasta lokacyjnego w Sandomierzu w XIII-XIV wieku, „Roczniki Historyczne” 2016, nr 82, pp. 79-106.

Okniński P., Uwarunkowania początków rozwoju polskich kancelarii miejskich na przykładzie Krakowa (do 1312 r.), [in]: Loca scribendi. Miejsca $i$ środowiska tworzace kulture 
pisma $w$ dawnej Rzeczypospolitej XV-XVIII stulecia, red. A. Adamska, A. Bartoszewicz, M. Ptaszyński, Warszawa 2012, pp. 27-45.

Orłowska A., W sprawie polityki handlowej Kazimierza Wielkiego, [in:] Z dziejów średniowiecznej Europy Środkowo-Wschodniej. Zbiór studiów, red. J. Tyszkiewicz cz. 2, Warszawa 2007, pp. 153-165.

Ptaśnik J., Studia nad patrycjatem krakowskim wieków średnich, „Rocznik Krakowski” 1913, nr 15, pp. 23-95.

Resztak M., Najstarsza zachowana lubelska ksiega miejska i jej pisarze, cz. 1, „Studia Źródłoznawcze” 2013, nr 51, pp. 3-18.

Resztak M., Najstarsza zachowana lubelska księga miejska i jej pisarze, cz. 2, „Studia Źródłoznawcze" 2014, nr 52, pp. 23-43.

Resztak M., Ze studiów nad kultura prawna kancelarii miejskiej późnośredniowiecznego Lublina, [in:] Coram iudicio. Studia z dziejów kultury prawnej w miastach późnośredniowiecznej Polski, red. A. Bartoszewicz, Warszawa 2013, pp. 109-130.

Riabinin J., Materiaty do historii miasta Lublina 1317-1792, Lublin 1938.

Rola A., Historia podlubelskiej wsi Konopnica do połowy XVI wieku, „Rocznik Lubelski” 2013, nr 39, pp. 9-19.

Rozwałka A., Lubelskie wzgórze staromiejskie w procesie formowania średniowiecznego miasta, Lublin 1997.

Rozwałka A., Sieć osadnicza w archidiakonacie lubelskim w średniowieczu. Studium archeologiczno-historyczne, Lublin 1999.

Rozwałka A., Zarys stanu badań archeologicznych i historycznych średniowiecznego Lublina, [in:] Lublin przez wieki. Szkice z badań archeologicznych, red. E. Banasiewicz-Szykuła, Lublin 2004, pp. 35-52.

Rozwałka A., Niedźwiadek R., Stasiak M., Lublin wczesnośredniowieczny. Studium rozwoju przestrzennego, Warszawa 2006.

Rozwałka A., Stasiak M., Dominikanie a przestrzeń miejska średniowiecznego Lublina, [in:] Dominikanie w Lublinie. Studia z dziejów kultury, red. H. Gapski, Lublin 2006, pp. 59-71.

Samsonowicz H., Przemiany osi drożnych w Polsce późnego średniowiecza, „Przegląd Historyczny” 1973, nr 64, pp. 697-716.

Samsonowicz H., Szlak battycko-czarnomorski w XIII-XIV wieku, [in:] Balticum. Studia $z$ dziejów polityki, gospodarki i kultury XII-XVII wieku ofiarowane Marianowi Biskupowi w siedemdziesiąta rocznicę urodzin, red. Z.H. Nowak, Torun 1992, pp. 285-290.

Słownik historyczno-geograficzny województwa lubelskiego w średniowieczu, t. 3: Dzieje Lubelszczyzny, oprac. S. Kuraś, Warszawa 1983, pp. 39, 107.

Sochacka A., Organizacja zarząu dóbr ziemskich $w$ województwie lubelskim $w$ średniowieczu, „Rocznik Lubelski” 1985-1986, nr 27-28, pp. 31-50.

Sochacka A., Polityczne $i$ administracyjne zwiazki terytorium lubelskiego z Sandomierzem w średniowieczu, [in:] Sandomierz - z dziejów polityki, prawa i kultury, red. A. Wrzyszcz, Sandomierz 2001, pp. 74-88.

Stankowa M., Kancelaria miasta Lublina XIV-XVIII w., Warszawa 1968.

Starzyński M., Spór o miasto. Kraków w ostatnim dziesięcioleciu panowania Kazimierza Wielkiego, [in:] Kazimierz - sławny i z czynów wielki, red. M. Starzyński, Kraków 2011, pp. 85-95.

Sułowski Z., Przedlokacyjny Lublin w świetle źródet pisanych, [in:] Dzieje Lublina. Próba syntezy, red. J. Mazurkiewicz, t. 1, Lublin 1965, pp. 30-42.

Szacherska S.M., Płock - civitas vetus czy civitas cathedralis?, [in:] Spoleczeństwo Polski średniowiecznej, red. S.K. Kuczyński, t. 5, Warszawa 1992, pp. 186-187.

Szafran P., Rozwój średniowiecznej sieci parafialnej w Lubelskiem, Lublin 1958.

Szczygieł R., Lokacja i rozwój Lublina w XIV w. Na drodze ku świetności [in print]. 
Szczygieł R., Wokół lokacji Lublina na prawie niemieckim, [in:] Hereditas praeteriti additamenta archaeologica et historica dedicata Ioanni Gurba Octogesimo Anno Nascendi, red. H. Taras, A. Zakościelna, Lublin 2009, pp. 501-508.

Szczygieł R., Zmiany centrum handlowego Lublina od XIV do XVII wieku, „Kwartalnik Historii Kultury Materialnej” 1992, nr 3, pp. 313-318.

Szymański J., Dokument lokacyjny Władysława Eokietka dla Lublina z 1317 roku, [in:] Lublin 1317-1967, red. H. Zins, Lublin 1967, pp. 271-287.

Teterycz-Puzio A., Geneza województwa sandomierskiego. Terytorium i miejsce w strukturze państwa polskiego w średniowieczu, Słupsk 2001.

Teterycz-Puzio A., Przyczyny i cele najazdów litewskich na ziemię sandomierska w XIII w., „Rocznik Lubelski” 2009, nr 35, pp. 9-22.

Trojanowska M., Dokument miejski lubelski od XIV do XVIII wieku. Studium dyplomatyczne, Warszawa 1977.

Trojanowska M., Katalog pieczęci miasta Lublina od roku 1317 do roku 1811, „Archeion” 1974, nr 60-61, pp. 105-123.

Trojanowska M., Pieczęcie miasta Lublina od roku 1317 do roku 1811, „Archeion” 1974, nr 60-61, pp. 81-104.

Urzędnicy małopolscy XII-XV wieku. Spisy, oprac. J. Kurtyka, Wrocław 1990.

Weber M., Die Stadt, „Archiv für Sozialwissenschaft und Sozialpolitik“1921, Bd. 47, pp. 621-772.

Widawski J., Miejskie mury obronne w państwie polskim do poczatku XV wieku, Warszawa 1973.

Wyrozumski J., Maciej, [w:] Polski słownik biograficzny, red. E. Rostworowski, t. 19, Wrocław 1974.

Zientara B., Przełom $w$ rozwoju miast środkowoeuropejskich $w$ pierwszej połowie XIII wieku, „Przegląd Historyczny” 1976, nr 67, pp. 219-243.

Zientara B., Przemiany spoleczno-gospodarcze i przestrzenne miast $w$ dobie lokacji, [in:] Miasta doby feudalnej w Europie środkowo-wschodniej. Przemiany społeczne a uklady przestrzenne, red. A. Gieysztor, T. Rosłanowski, Warszawa 1976, pp. 67-97.

Żmudzki P., Studium podzielonego Królestwa. Książę Leszek Czarny, Warszawa 2000.

\section{STRESZCZENIE}

Artykuł dotyczy formowania się struktur instytucjonalnych i ram przestrzennych późnośredniowiecznego osadnictwa miejskiego, które rozwinęły się w ciągu XIII i XIV stulecia na Wzgórzu Staromiejskim w Lublinie. Autor reinterpretuje ustalenia wcześniejszych badań nad historią Lublina w świetle koncepcji Maxa Webera o zachodnioeuropejskim modelu miasta komunalnego. Miasto tego typu jest charakteryzowane jako autonomiczna jednostka administracyjna, posiadająca własny samorząd gminny i system sądownictwa, jak również jako podmiot terytorialny z określonymi granicami. Autor wyróżnia trzy etapy rozwoju miejskiego w Lublinie: 1) powstanie wczesnomiejskiego osadnictwa wzdłuż dzisiejszej ulicy Grodzkiej, w sąsiedztwie kościoła św. Michała Archanioła w XIII w., 2) wprowadzenie prawa miejskiego i stworzenie nowego układu urbanistycznego przez Władysława Łokietka i Kazimierza Wielkiego, 3) gwałtowne przyspieszenie rozwoju instytucjonalnego i przestrzennego po śmierci Kazimierza.

Słowa kluczowe: kolonizacja; lokacja; samorząd miejski; ratusz; kancelaria miejska; układ urbanistyczny; urbanizacja 